\title{
Infantile Hemangioma
}

National Cancer Institute

\section{Source}

National Cancer Institute. Infantile Hemangioma. NCI Thesaurus. Code C6645.

A capillary hemangioma that may regress spontaneously. It occurs in infants and children. 